\title{
Government, Political Actors and Gover- nance in Urban Policies in Brazil and São Paulo: Concepts for a Future Research Agenda
}

\author{
Eduardo Marques \\ Department of Political Science, University of São Paulo (DCP/USP) and Center for Metropolitan \\ Studies (CEM), Brazil
}

Public policies are produced by connections between several actors, within institutional environments and crossing organizational boundaries, but detailed analyses of the environments in which politics occur are relatively rare in Brazil. I believe the concept of governance could help to bridge this gap. However, this concept has different meanings and has been circulated in Latin America with quite confusing and cacophonic meanings. In this analytical essay, I build a definition of governance based both on local debates and the recent international literature, which can be of use to study urban policies in Brazil, going beyond government but specifying the elements under investigation.

The article starts by critically discussing the uses of the concept of governance in Latin America and especially in Brazil, highlighting some of the most important problems of the existing analyses, so as to forge an alternate operational definition. I then discuss the most relevant political actors present in Brazilian urban policies and later use these elements to discuss the governance of policies regarding the production of the built environment.

Keywords: Governance; urban policies; government; political actors; Brazil.

\section{Introduction}

ublic policies are based on the connections between several actors, within inactions involve conflicts, interests, ideas and inequalities in political resources. Although 
these ideas are almost undisputed in the international literature, they tend to have only a small influence in Latin American social sciences.

I believe the concept of governance can be key to introducing these ideas. However, it has several different meanings (Rhodes, 1996; Stoker, 1998) and perhaps some authors have expected more from it than a concept can deliver (Kooiman et al, 2008). In Latin America, governance has had quite confusing and cacophonic meanings, some of them the product of an uncritical incorporation of the international dissemination of the concept. In this article, I will build an analytical definition of governance based both on local debates and on the recent international literature in order to broaden the focus of policy studies in Brazil beyond government, and to particularize the elements under investigation at the same time. The production of empirical analyses lies ahead as a research agenda targeted to map the existing local governance patterns and to bridge politics and policies analytically.

The article is divided into three parts, beside this introduction and the conclusion. I will start by critically discussing the uses of the concept of governance in Latin America and especially in Brazil, highlighting some of the most important problems of the existing analyses so to forge an alternate operational definition. The second section discusses the most relevant political actors present in Brazilian urban policies. The third section uses these elements to discuss the recent governance of policies for the production of the built environment in São Paulo. In the concluding section, I will summarize the main elements under analysis.

\section{The Ideas of Governance in Latin America and Brazil -Restructuring the Brazilian State and Deepening Brazilian Democracy}

Governance has been used with very different meanings. It is not in this article's remit to discuss the definitions in the international literature, since this has already been done by authors such as Rhodes (1996) and Stoker (1998). The concept has been used to shed light on a wide variety of themes, and has been considered as a structure (of rules and institutions), as processes (or ways of producing policies), as a mechanism (to forge cooperation or to reduce transaction costs, for example), and also as a strategy, or governancing (Levi-Faur, 2012). ${ }^{1}$

This section discusses the most common uses of the concept of governance in Latin America and in Brazil. In some cases, governance only serves as a metaphor for government (Ivo, 1997), according to some international debates (Wilson, 2000; Wilson, Spink,

1 Important reviews have already been made by Rhodes (1996) and Stoker (1998). A systematic compilation of governance uses can also be found in Levi-Faur (2012). 
Ward, 2011). In other cases, the concept means the government of policies which present strong interdependency, such as metropolitan issues (Azevedo and Mares-Guia, 2000) or water management (Abers and Keck, 2009; Jacobi, 2005), with varying emphases on social participation.

In general, however, governance in Brazil is associated with two different forms of organizing government, leading to two diverse sets of results, considered very different in political terms. But as we will see, there are several similarities between these uses. Firstly, they are both associated with local changes in government that have happened since the return to democracy, although under the influence of different global tendencies and of the international migration of ideas. They are associated with the two main political forces that polarize electoral competition in this country, but are both associated with proposals based on strong suspicions of the State.

\section{Public Management, State Reduction and the Integration of Private Actors}

In this case, the term governance emerged in the 1990s to designate a specific process of policy-making involving state agencies and private actors, with a clear association with State reform, in dialogue with international debates on State reduction and new public management. ${ }^{2}$ Governance in this case is based on diagnostics of State failures and would be 'fresh and wanted news', something to be built by specific policies in order to reform the State apparatus, enabling better policies with less government. ${ }^{3}$

Many are the lines which led to this view of governance that sees the State in a negative light, influenced by the New Public Management perspective in Western countries since the 1970s, especially regarding the management of their economies and the contention for public spending (OECD, 1995). More efficiency and accountability in the public sector was achieved by introducing competition with private companies, as well as by importing private sector management tools into State agencies. A central element became the reduction of bureaucracy and the removal of some public management sectors away from political control by submitting them to market control. However, it soon became clear that the mere neoliberal prescription centered only on reducing the State was not going to be sufficient for promoting development.

2 Rhodes (1996) sustains that the term governance has had six uses in the international literature: minimal state, corporate governance, new public management, good governance, social-cybernetic systems and self-organizing networks.

3 One of the most disseminated uses of governance is in business administration and focuses on corporate governance - Rhodes's (1996) second use. 
Part of the international debate even questioned the assumptions used to justify market efficiency in new State functions, especially the regulatory ones, echoing neo institutionalism in economics. So instead of less State, the task would involve reformulating the State to separate the role of regulator from the role of conductor of development. The creation of new agencies was necessary for regulating and promoting the private production of public goods, whether by introducing private competition to public agencies or by privatizing the provision of public services. This would demand the construction of incentive structures and regulatory institutions to lead actors, including the State, to act in accordance with public interest. The latter should be distinguished from the interests of the State, and for this reason, regulation activities would be placed outside of the control of political institutions.

In the Brazilian case, the arrival of these ideas also meant the interruption of our long cycle of import-substitution industrialization and the breaking down of political coalitions based on national developmentalism (Diniz, 2003). State reform and particularly policies of public spending adjustments were strongly influenced by these ideas, although in Brazil social policies remained separate from this type of influence, being impacted by policy-specific processes.

The local discussions on State reform were intense, although most of them happened during Fernando Henrique Cardoso's administrations, which fully embraced this. According to this view, governability and governance should be kept separate and understood as two different State capacities. Governability refers to the conditions that guarantee public policymaking, while governance should be understood as the "financial and administrative conditions that a government has for transforming into reality the decisions it makes" (Bresser Pereira, 1997, p. 7) or "the capacity to effect the decisions of governments" (ibid, p. 18).

These ideas were especially supported after the creation of MARE - the 'Ministry of Federal Administration and State Reform', presided over by economist and academic Luis Carlos Bresser Pereira, a political entrepreneur of these ideas in the years that followed. The proposal included a redrawing of State boundaries, defining exclusive areas for state action and others which would be either made public (but not state-owned) or privatized. The reform managed to approve several legislations, but was not successful when it came to implementation, according to its own formulator (Bresser, 2001). The debate on the reform was intense, although focused mainly on the government's views disseminated by publications by the Ministry (several of them with the Minister himself as author) and the National School of Public Administration - ENAP (see Araújo, 2002, for example) affiliated to the Ministry. For obvious reasons, this literature was marked by strong optimism. ${ }^{4}$

$4 \quad$ It is worth noting that there were some voices questioning the effects of these transformations even inside the debate. For example, in a book co-edited by the Minister himself titled 'State 
The reform produced consequences both in terms of policies and political debates concerning the State, but the accumulation of knowledge about the ways in which the State operates and its relations with actors from its surroundings was quite restricted. This was due to the fact that the reform was based on the assumption that the State could be thought of as if it were outside the political system or even separate from politics. Except for the studies on regulatory agencies, this line of analysis declined quite steadily from the 2000s, largely due to the victory of a political coalition which once again placed State reform at the center of the agenda (and of political disputes) through redistribution and economic development led by the State. The speed of the decline of State reform in academic debates reveals how much the research agenda in Brazilian social sciences is oriented by political conjunctures instead of research problems, making the accumulation of long term knowledge a difficult task.

Another line of analysis which disseminated a governance concept close to this in Latin America and Africa came from multilateral organizations, especially the World Bank and the OECD. In the 1980s, these organizations promoted policies of structural adjustments in poor countries which ignored local contexts and political conditions. A generation of policy failures in development programs led to rising criticisms against these organizations, and their next generation of policies incorporated, at least in part, local political dynamics and institutions. Themes like corruption, institutional construction, consensus building, accountability, legitimacy and sustainability entered the agenda of these institutions strongly from the 1990s. This agenda clearly dialogues with State: "Africa needs not just less government but better government..." (The WORLD BANK, 1989, p. 5).Governance is defined in a broad and imprecise manner, as "the exercise of political power to manage a nation's affairs" (p. 60), although this is associated with the promotion of good governance- "a public service that is effective, a judicial system that is reliable and an administration that is accountable to its public" (p. xii).

According to Moore (1993, p. 2), these ideas, as expressed in World Bank (1992), can be read as "a set of signals intended to influence the thinking of the rest of the world, notably the governments of the Bank's client countries about what constitutes good government, and therefore what they should themselves be doing independently of the Bank". Despite the fact that institutional designs and political regimes were out of the Bank's reach and that these have never been the object of intervention by donors and multilateral agencies, the idea of governance opened a path to influence government structures and capacities. Therefore, in this case also, the term is associated with a set of positive elements concerning government activities, as well as with an agenda that could lead to produce them, by promoting several other agendas of institutional reform. The State is a possible source of inefficiency, but this can be solved by developing new institutions.

Reform and the New Public Management', Spink (1999) stated that "it should be pointed out here that a more detailed examination of the history of the attempted public administration reforms should, at least, raise serious doubts concerning the optimism and course of current activities" (p. 142). However, the general tone of the debate was of strong expectation and even some triumphalism. 


\section{Democratic Governance/Social Participation}

For another significant part of the literature in Latin America and Brazil, the concept of governance is connected to issues of social participation, democracy, social control and social movements in several policy areas. In a way, governance here occupied the same role that the idea of poder local (local power) had occupied in the 1980s. This concept was used in Brazil during the redemocratization process with no connection to international debates on local power and was used to describe a mixture of decentralization, democratization and participation at local levels. ${ }^{5}$

In empirical terms, this literature focuses on the recent creation of participatory institutions in the aftermath of Brazilian redemocratization, including the creation of Policy Councils, Participative Budgeting and National Conferences (Abers and Keck, 2009; Cardoso and Valle, 2000; Frey, 2007; Jacobi, 2005; Ribeiro, 2012; Santos Jr., 2002). These were sometimes seen as spaces of deliberative democracy, but were also considered by others as neocorporativist arenas (Cortez and Gugliano, 2010).

Most of this production does not specify the concept of governance they are working with, although most of the texts suggest that the definition includes certain government results - "more accountability from municipal governments concerning social policies and the demands of their citizens; the acknowledgment of social rights for all citizens; opening channels for broad civic participation by society" (Santos Jr., 2002, p. 88). It is also in this sense that Ribeiro (2012) assumes that low levels of associativism and the existing political culture hinder the advancement of metropolitan governance (p. 12). Although a precise definition is not presented, apparently it involves normatively defined government results in decentralized environments, where local participative policy-making is grounded in intergovernmental cooperation (p. 72). This could also happen through networks in participatory arenas (Frey, 2007). The main thematic areas that use the notion of governance as a strategy to enhance participation are urban studies (Frey, 2007; Ribeiro, 2012; Santos Jr., 2002), housing (Cardoso and Valle, 2000) and the environment (Abers and Keck, 2009; Jacobi, 2005).

As with the previous literature, the State is seen with suspicion, in this case due to being a source of control and tutelage, which can be softened by developing social control and institutionalized participation. Similarly to the previous perspective, the term governance may be applied only when the policy process contains certain elements or leads to

5 This use is absent from both Rhodes's (1996) and Stoker's (1998) classifications. Democratic governance and participation, however, also appear in international debates, but usually associated with the idea of collaborative governance such as in Ansell (2012). 
certain results. But while the former is interested in changes in the institutional design that lead to efficiency, this one is interested in changes that enlarge participation.

Although there are exceptions, the majority of this production does not consider the intense transformations brought about by democracy to State/society relationships in Brazil, except for some references to federalism. The consequence is that this literature thus undermined two central elements -the importance of political parties and the specificities of recent public policy reforms. At least in part, this is caused by still thinking participation and social movements are associated with autonomy, as if their mobilizations were not built within tight networks that tie them to other social actors (including the State) and as if their demands were not socially built in constant dialogue with political frames and with sets of rights and policies consolidated in (and by) political institutions.

A more recent literature on social movements in Brazil, in contrast, departs from the neoinstitutionalist concept of fit, bringing to the center of the analysis the multiple connections between State and civil society organizations (Gurza Lavalle, Castello and Bichir, 2008; Tatagiba, 2011). Having kept a safe distance from the idea of the autonomy of movements, this line of investigation produces a better understanding of the multiple connections between mobilizations and political institutions and could generate a fruitful dialogue with the expanded notion of governance presented here.

Finally, a methodological element must be raised. By defining governance only as policy designs and policy processes that lead to good results (however they are defined by efficiency or participation), these literatures hamper the possibility of discovering why good results are produced. In methodological terms, this implies the problem of selection by the dependent variable. It is possible to understand success only if cases of success and failure are compared. Similarly, if studies of governance include only the cases with desirable results, they will not be able to achieve their own goals.

It is worth noting a third group of studies which, although does not constitute a debate in itself, is located between State reform and democratic governance and anchors the idea of governance within the political system through the idea of accountability. However, for some of these authors, a strong normative dimension remains in the definition of governance. Boschi (2003) defines governance as "formats of public management which, founded in the interaction between public and private, would assure transparency in the formalization and efficacy of the implementation of policies" (p. 1). This normative bias is also present in Diniz (2003), who, after thoroughly discussing the origin and nature of the recent State transformations, defined governance as the "state action capacity to implement policies and attain collective targets" (p. 22). Governance, then, is more associated with a (positive) capacity than with a configuration of actors/relations within certain institutions. Ckagnazaroff (2009) follows a similar direction, defining democratic 
governance as "processes deriving from the relationship between government and civil society in the attainment of public objectives" (p. 24).

In reality, few authors have considered the links between institutions and actors and simultaneously kept a safe distance from normative visions of the concept, avoiding the pre-definition of political outcomes. Azevedo and Mares-Guia (2000, p. 10) do this when they state that governance "surpasses the dimension of administrative performance, also involving the system of interest intermediation, especially when it refers to the ways organized groups from society participate in the process of definition, oversight and implementation of public policies". Subsequently, in an empirical analysis of the way metropolitan agencies in Belo Horizonte operate, they keep a simultaneous focus on institutions and on political process. In yet another contribution, Azevedo (2000) expresses that "governance is not limited to the institutional and administrative format of the State or to more or less efficacy by the State apparatus when implementing policies ... the concept of governance qualifies the manner of using this authority".

In my opinion, none of these concepts is fully applicable to the study of urban policies in Brazil. In fact, these interpretations have resulted in the dissemination of fictions about policies and about the politics that surround them. There are at least seven important fictions, which can be summarized as follows:

a. From government to governance - Governance has been presented as an alternative to government, but there is no arrangement among actors that could replace government in terms of policy-making (Stoker, 1998), whatever the design. This idea, sometimes implicit, probably originates from the anti-state bias of the two hegemonic paradigms listed above. Any governance arrangement involves large quantities of government and of plain and old State actions.

b. Governance is necessarily positive -This is true only if at least one of three conditions are present in politics: i) political actors should always be operating for the common good; ii) certain actors should always behave this way, and they should be hegemonic; iii) some institutions should force them to do it. Political systems vary substantially but it does not seem logical to expect any of these alternatives in a realistic political world. But this assumption appears in different forms in the governance literature.

c. Governance makes hierarchies disappear, by producing horizontality- There are good reasons to sustain neither the elimination of hierarchies, nor their substitution for horizontality. In fact, against common sense, even networks are full of hierarchies considering positions, structures, accesses and flows. Besides that, actors participate in political processes with the resources available to them and, as resource inequalities have not been diminished by the mere inclusion of other actors in policy-making, there are no reasons to believe in plain horizontality. 
d. Similarly, by promoting participation, governance could mean more democracy the literature in public policies has already shown that depending on policy design, but also on political processes, institutionalized participation may lead to capture from organized groups, especially within corporatist structures, and not to democracy (Pierre, 2011).

e. Governance as efficiency or capacity - Already present in the literature discussing State reform, this problem survives to date due to the idea that local governance is "processes deriving from the relationship between government and civil society in the attainment of public objectives" (Ckagnazaroff, 2009). Differently, Le Galès (2011) defines governance as a "process ... to attain particular goals". The replacement of 'public' by 'particular' here removes the normative drive and allows the analyses to find several empirically possible results. Everything may go wrong even if all the 'good' institutional designs are present, and finding out whom these goals benefit must be a product of the analysis and not part of the concept's definition.

f. Governance involves prescriptive or normative dimensions - This use of the concept would leave us free to conjecture about 'good government' or 'best practices'. An obvious observation regarding the first expression is the specification of to whom government should be good to. As we have already been aware since at least Joseph Schumpeter, it is not simply possible to specify a general will or a common good in politics.

g. Additionally, the idea of best practices - Rhodes's (1996) fourth use of governance - was recently intensely disseminated by the World Bank. Although this idea was not produced by the social sciences (nor by academic debates, in fact), it has been influencing discussions on poverty and on social policies since the 1990s. In Brazil, some authors have tried to develop an alternate concept of good practices (Farah, 2007), which differs from the World Bank's because it allows several possible solutions for each policy problem. Although this is an important development, both ideas assume that: i) policies can 'travel' between contexts and ii) the design and implementation of good policies mainly involves finding good technical solutions. And it is more than established that policies 'travel' with great difficulty to different local conditions. In fact, political science has already shown since at least the 1950s that political processes - actors, conflicts, alliances - and local conditions (institutions among others) are the elements that define how State initiatives will reach their end. In fact, we learn more about the functioning of governments and their policies by studying the 'worst practices' (and understanding what did not work) than by studying the best.

How do we define governance then, in order to take advantage of the potentialities of the concept without incurring the problems discussed above? Following Stoker (1998) and Le Galès (2011), I define governance as sets of State and non-State actors interconnected by formal and informal ties operating within the policy-making process and embedded 
in specific institutional settings. Let us take a closer look at the various elements of this definition.

The distinctions between State and society and between politics and policies are analytical and although each of these fields is associated with specific characteristics, actors and other different elements, numerous forms of connection are present among them, influencing the political process. All policy-making phases involve multiple State and nonState actors who act and exert their influence on policies. The concept of governance allows a systematic incorporation of other non-State actors, but accepts the existence of blurred boundaries (Stoker, 1998) between them.

Moreover, the policy-making process is hardly ever autarchic in the sense of power emanating from a single decision maker or implementer, and organizations depend on others (Stoker, 1998). We have known this at least since Lindblom's idea of disjoined incrementalism, which proved the intrinsic interactive nature of the subject, predating the idea of interactive governance of Kooiman et al (2008) by a few years.

Differently from very important references in the literature (Rhodes, 1996), however, I do not believe governance is only self-organizing networks, but also the institutions and organizations that surround these actors, as well as their configurations and power resources or, to use an old fashioned expression, the existing 'power structure'.

Following this same line of reasoning, governance should be understood as arrangements among actors based on networks of relations, and distinct from other arrangements organized by i) markets or ii) hierarchies (Rhodes, 1996; 2006). Although agreeing again with the centrality of networks, I believe this is not necessarily the best interpretation we can have, since networks are present in these other spheres as well. In markets, they structure exchange relations - as a wide literature on economic sociology has shown - and in organizations (including the State), hierarchies are combined and superposed with networks, as thematized by Hugh Heclo and later by the policy networks literature (Laumann and Knoke, 1987). Networks are the fabric of society and they are present in various and mutating forms connecting actors in diverse ways.

Besides that, the idea of governance admits the incorporation of informal and even illegal processes which, on many occasions, affect policies. These have sometimes been understood as noises, defects or minor problems that should (and can) be eliminated, therefore not worthy of analytical attention, even for the policy networks literature (Laumann and Knoke, 1987), centered only on formal and intentional ties. From my perspective, a significant part of the policy-making process involves informal activities and relations. Several of the existing organizational ties are, in fact, personal and informal relationships mobilized on formal occasions but constructed for other purposes or with no purpose at all. 
Additionally, a significant part of policy processes involve negative elements, failures, errors and even illegal processes. This happens not only in Latin America, but also in countries with much more consolidated institutions, as exemplified the by iron triangles in the US (Fiorina, 1989) or by the difficulties in steering networks between organizations in Europe (Rhodes, 1996). The concept of governance may precisely allow the incorporation of such dimensions empirically, but an aprioristic positive interpretation of governance prevents this from happening. As previously mentioned, it is only the inclusion of these 'dark sides' of governance that can allow us to discover why they happen.

Lastly, the idea of governance enables the incorporation of various arrangements between actors and institutions into a single analytical concept, making many situations comparable. There exist several types of governance, something already discussed by Pierre (2011) and Stone (1993) using the concept of types of regime. But the idea stated here is not just the existence of several governance patterns, considering their diverse characteristics. Several of them may coexist in the same place and at the same time, for example, in different policy areas. The comparative study of those patterns may suggest important ways in which to understand how different configurations of actors, institutions and networks interact to create diverse governance conditions. The following sections explore this for the case of São Paulo.

\section{Actors, Institutional Legacies and Policies}

In the case of urban policies, it is possible to theoretically discuss the importance of four groups of actors in urban governance patterns -bureaucracies and state agencies from different levels of government; politicians and political parties; private companies that retrieve their valorization processes from the production of the city and social movements. In Brazil, one of the most general institutional features to be considered is federalism, with three tiers of government. In the large majority of policy sectors today, federal government plays an important decision-making role, but local governments (states or municipalities, depending on the policy) have prominent roles in service delivery and on implementation (Arretche, 2012). Policy legacies, however, tend to be marked by the histories of each sector, which define policy responsibilities for each level of government. In the case of urban policies, planning, land use control, public transportation by bus, and garbage collection are provided by municipalities, while public transportation by rail, policing and environmental regulations are clearly under state control. Housing, traffic control, sanitation and drainage are provided by both states and municipalities depending on the presence of local companies and concession agreements. A substantial part of these services is contracted 
to private companies, which helps to explain the importance of the urban capitals discussed below.

These features of Brazilian federalism give important specificities to the formation of local political coalitions. Differently from the case of the US, local governments have access to relatively stable financial resources for policies in Brazil, as they do in Europe (Harding, 1997). In the large and richer municipalities these come from both local tax bases (land property and services) and federal transferences, but even small and poor municipalities have access to funds from automatic and earmarked federal transferences (Arretche, 2012). So, although promoting growth may be an important political goal (and powerful political discourse), it is not the most common and stable base for elite coalitions, such as in the case of Molotch's (1976) growth machines. On the other hand, in the Brazilian case, private companies are central for electoral campaign financing, both through legal and illegal contributions. But this may be achieved by establishing strong relations with private contractors of public services and public works. So, urban coalitions in Brazil may be based on land production and urban renewal, but also on large scale public construction projects. This may happen for political reasons, but not for fiscal reasons.

Another important institutional feature is the presence of what the literature has called coalition presidentialism. Since the return to democracy, no Brazilian president has had control over the legislative houses, but the large majority of the approved legislation has been sent by the presidency and approved. This has been due to a combination of legislative powers in the hands of the presidency and several institutions within the legislative chambers that gave great power to party and congressional leaders, forging party discipline. Additionally, occupation of key institutional positions in the executive has been intensely negotiated between the presidency and the parties, leading to a presidential model with strong traces of parliamentarism. The result is a strong executive (contrary to the hypothesis of the hegemonic literature), but with its strength depending on negotiations with the parties (Figueiredo and Limongi, 1999).

The role of the judiciary branch has also been reinforced, both with regards to some tendencies towards a judicialization of politics and to the new roles occupied by the Ministério Público, entitled by the Constitution as the defender of so-called diffused rights. Due to this responsibility, the Ministério Público may start judicial processes without the involvement of the individual or the group whose right has been violated. This new institution has produced important effects on social policies.

Although national, these characteristics are also present at the state and municipal levels. Existing studies suggest that in cities, or at least in São Paulo, the role of aldermen is minor in terms of proposing legislation (especially legislation which is not in the mayor's agenda), except for the approval of major urban legislations such as Master Plans and 
Land Use laws, when aldermen occupy a key role in decision-making processes, and when different social groups intensely lobby the legislative. But most of the time, their influence on policies is carried out by occupying executive positions, in exchange for legislative support. At least since the mid-1980s, this power has been exercised through the control of the aldermen over a significant part of the local services delivered by the regional administrations (now Submunicipalities) responsible for small street paving, garbage collection and other daily maintenance services. Recent administrative decentralization reforms have enlarged the list of services provided by these decentralized units. These local powers are granted by mayors to aldermen, since they almost never win majorities electorally, and have to build broad party alliances. Local bureaucracies tend to be feeble in the majority of municipalities, although their capacities are growing fast, in great part due to federal induction (Arretche, 2012).

Besides politicians and political parties, elite actors include for profit enterprises, or urban capitals. But by urban capitals I do not mean collective or individual actions of capitalists interests located in cities in some form of local corporatism.

The truly relevant group of capitals for urban policies is the one that extracts their valorization processes directly from the production and functioning of the city. They include at least three different types, considering their relations with the State and the role of urban land in their valorization processes.

A first type of urban capitals includes the development industry, already addressed by Marxist urban sociology. Their valorization cycles are strongly dependent on land availability and become crystallized in specific locations. Their products are sold directly in the market, which tends to be competitive, except for projects built in very important locations. During each cycle, these capitals interact with building companies and with landowners (and may superpose them), but their profits have very different origins. While building companies seek industrial profits and landowners charge for land use, developers profit from the development of projects which change land values by changing land use. Since land is not produced, its price is associated with the uses it receives. By changing the land use, developers change land prices, creating their profit. The State influences profit rates by creating regulations and planning, but it is not a direct buyer. The stronger emphasis of the literature on the role of these actors is justified by their capacity to transform land occupation and, by doing so, to create spatial tendencies that influence entire regions of the city. In the case of São Paulo, the most important collective actor representing the sector is SECOVI, the developers' association. Its collective action is usually observed during the approval of municipal laws - Master Plans, Land Regulations etc. -,lobbying for the sector, although the pressure during most of the time tends to be individualized. 
Considering the centrality of land use transformation in their actions, the interests of developers are strongly entrenched in space.

The development industry has changed in São Paulo in the last few decades, in part following the changes in the national housing markets. At least three production cycles have happened since the return to democracy. The first two - from 1985 to 1993 and from 1993 and 2003 - were highly concentrated spatially in the expanded center and focused on higher income production, especially during the first period (Marques, 2005). Shimbo (2012) recently showed the existence of a third cycle starting in 2004, with a much larger amount of housing units of lower value aimed at the lower middle classes and constructed by larger companies, enabled by developers' capital going public in the stock market from 2006 (Shimbo, 2012). During this new cycle, the market share of low and middle income units increased substantially and the location of the projects tended to be less concentrated in the central areas.

The second type of urban capitals includes those involved in the production of urban infra-structures. In terms of production process they have similarities in common with the construction industry in general. They organize industrial processes - combining production factors to create merchandise, but in this case land is not an issue, or at least not a central issue for their valorizations processes. Location is defined by the buyers of their services, namely private developers (who create settlements that need infra-structure) or the State (which buys urban infra-structure generally), and the availability of land is solved by these buyers. As I suggested in Marques (2000 and 2003), the large majority of this market works as an oligopsony - several sellers but few large buyers, which are mainly State agencies creating bids and contracting public works. Therefore, price formation and the quantities and qualities of products in these markets depend substantially on what happens within the State. These markets have, as a consequence, intrinsic political features, and private companies have strong incentives to try to influence what happens within the State. For this reason, political corruption tends to be present.

A third and last group of capitals involves urban service providers such as transportation and garbage collection. As in the previous case, the State is almost the only buyer, repeating the oligopsonic structure of competition, as well as the political nature of the market. Differently from it, however, the contracts are not located in time and space, but spatially scattered and temporally long lasting, and the importance of urban land is low. This creates specificities for governance patterns, as we will see later. Another specificity is that in this case, it is the functioning and maintenance of the city that are at stake, which makes this sector much less affected by financial and fiscal crises than the previous ones.

An additional remark about urban capitals must to be made, considering their centrality among national private companies in Brazil. Considering the historical construction 
of the Brazilian economy, both the State and private foreign companies played major roles from the 1930s, with a new important surge in the 1970s. They became engaged, respectively, in infrastructure/intermediary goods and in the most modern branches of the transformation industry (Lessa and Dain, 1982). Brazilian capitals specialized mainly in banking - a sector which was intensely privatized in the 1990s - and construction, one of the sectors in which Brazilian multinationals operate nowadays. This happened at all levels of the federation, leading to a strong involvement of local elites with construction and development companies. A considerable number of mayors and municipal secretaries are owners or co-owners of construction firms or urban development companies, which obviously creates great difficulties for the production of planning policies or the establishment of land regulations. This political difficulty is even greater because land has always been a very important economic asset for local elites, given the historical weaknesses of the country's financial markets.

At the other end of the social structure are popular actors. Social movements in São Paulo were very strong in the 1970s and 1980s and important actors of regime change during the transition from the military regime to democracy (Sader, 1988). During the 1980s, the metropolis hosted important movements and associations, mainly organized around health, sanitation and housing demands. From the 1990s, these movements forced an increase in service delivery, but also had a more diffuse effect associated with rerouting the local agenda towards distributive policies. This is especially true of the development of infra-structure policies in the peripheries and the creation and dissemination of slum upgrading initiatives. The production of large self-construction housing programs in the municipality of São Paulo and in other cities of the region was definitely influenced by (and sometimes pressured by) housing social movements. In this case, these local experiences created new policy alternatives, as well as a large policy community.

Urban social activism also became more heterogeneous from the 1990s, in part due to the presence of other channels of participation and political action under democracy, including NGOs and participation in public policy delivery. The sole issue in which social movements still tend to actively produce direct political actions in São Paulo is housing, especially the Central tenements movements, promoting the occupation of vacant building in the central area (Tatagiba, 2011).

At the same time, the democratic policy reforms substantially enhanced participation in policy processes through Policy Councils and Conferences (Tatagiba, 2011). Civil society organization has therefore been occupying a new role, going from 'active centrality' to 'passive centrality', according to some authors (Gurza Lavalle, Castello and Bichir, 2008). Councils spread during the 1990s in local governments and in the Cardoso administrations also became present at the federal level, as well as enforced locally by federal policies. 
On the other hand, more recently, several national Conferences according to policy were developed in order to enhance participation and include a larger number of participants than the ones seen in regular policy Councils.

This participation, together with the return of electoral politics, signified a very important increase in service delivery for the poor. Investments in the peripheries and the reduction of inequalities in access were issues that used to oppose left and right-wing governments until the 1990s, but presently all governments express the political will to face them (even if only in political discourse). The same can be said about slum upgrading policies, initiated in left-wing administrations but later spread to all governments. I believe this is due to several victories by the left (and the social movements) in a political environment increasingly controlled by elections, which dislocated the agenda towards more redistributive directions.

\section{The Governance of Urban Policies}

In Brazil, the abovementioned actors interact in various ways according to the existing literature. In fact, for a significant number of authors, the interpenetration between State and private actors was one of the constitutive characters of the Brazilian State. This lead to the formation of "bureaucratic rings" connecting groups from the State and the private sector (Cardoso, 1970) to the privatization and segmentation of the State or the constitution of highly privatized and poorly targeted social policies. This replaced the "intermediary organizations" present in other countries - political parties, trade unions and volunteer organizations. So, the Brazilian interest intermediation is distant both from European corporatism and US lobbying, involving actors personally connected to State agents. And consequently, the main arenas for political conflicts alliances and negotiations are not legislative bodies, or formal participatory institutions.

However, for this literature, interest intermediation would involve piecemeal, localized, intentional ties oriented towards a 'privatization of the State'. In Marques (2000 and 2003), I sustained a more continuous, sociological effect, connecting State and non-State actors through networks of individual bonds constructed over time, within policy communities based on what I called the relatively stable 'relational fabric of the State' (Marques, 2000).

This is also different from what the policy domain literature (Laumann and Knoke, 1987) has sustained, since these networks could just be part of larger social networks involving entities from within and without the State and linked by different types of connections. The framing of such a fabric might influence the political conflicts taking place inside the State, since actors use the relative positions they occupy as power resources. 
Besides that, this fabric would intermediate the permeability of the State to actors located both in society and in markets, specifying the interest in the intermediation patterns of each policy. So, the main arenas for political conflicts, alliances and negotiations would be State agencies and policy communities (and their networks). I will return to this in greater details in the next section.

Considering this, however, how are urban policies governed in São Paulo? The following discussion presents the existing patterns considering the literature. It is important to stress that these patterns sometimes interpenetrate, reinforcing or contradicting each another. Three broad patterns are present in São Paulo involving: i) universal social policies, ii) policing and violence control and iii)infrastructure policies, urban services, large urban projects and land use regulations. This paper details the analysis of the latter, associated more directly with the production of the city's built environment; the general features of the other two can be found in Marques (2012). This governance pattern, however, includes several subgroups, considering the different legacies and configurations of the actors and institutions involved. Therefore, the following discussion analyses four subtypes, considering their characteristics.

\section{Large Infra-structure Policies and Public Companies}

Policies are formulated and implemented within large state companies, with relatively low control from the outside. The decision and implementation arenas are internal to technical communities centered in the state companies. Policy change is sometimes produced by the technical community's internal dynamics, such as generational changes. But this may also happen through transformations in the connections between the community and the executive (Marques, 2000), although sometimes even elected politicians have difficulty controlling the technical communities who run the policies (Marques, 2003), depending on institutional and political elements. The role of legislative bodies and of collective lobbying is minimal. The main form of access involves the use of social networks by private interests to reach public officials. Their collective interests are associated with the adoption of certain policy solutions, as well as with influencing the bidding processes in terms of prices and conditions. Individual companies, in turn, are interested in being selected for public contracts. When corruption occurs, it is associated with illegal schemes aimed at producing victories in public bids in exchange for illegal private contributions to parties during elections, although in all cases individual there are also gains for the 'operators' of the schemes. It is a mistake, however, to consider that the large majority of policy is decided or influenced by corruption. The decision process tends to be technocratic, albeit influenced by both the interests of political parties and private companies. This pattern is 
not specific to urban policies and includes several areas associated with the production of large infra-structures (urban sanitation, subway, electricity and metropolitan trains, but also power dams, ports etc.).

This governance pattern was inherited from the military governments, when a special combination of closed decision processes within strong technocratic communities, special private access and lack of electoral controls were behind the expansion of the large majority of policy sectors. This pattern is especially present in policy sectors centered on state companies.

As mentioned previously, I call this interest intermediation pattern 'State permeability', associated with the relational fabric of the State and studied in detail in Marques (2000 and 2003). The first study analyzed water and sanitation infrastructure policies in the metropolitan region of Rio de Janeiro carried out by a state-owned company - Cedae - from 1975 to 1996. The company was created in 1975 following the merger of two Brazilian states into one (the former states of Rio de Janeiro and Guanabara) resulting in mergers of the existing agencies (in this case, three companies were merged to create a new one). The second study analyzed road infrastructure policies - paving, opening roads, curbs and gutters, minor drainage, bridges, viaducts and tunnels - developed by the Municipal Department between 1975 and 2000 in São Paulo. Therefore, these policies were developed in very different settings regarding insulation, career standards and availability of financial resources. In political terms, while Rio de Janeiro was marked by political polarization and alternation of power, in São Paulo there was a stable hegemony of a single political group throughout the period.

These investigations showed that the relational fabric of the State is composed of an overlap of thematic networks of connected communities including State technicians or bureaucracies, people demanding policies, contractors, and politicians and officials who occupy elected or designated positions. These networks have an inertial character, structuring the State from within, government after government. The relational fabric of the State thus builds continuities that structure influences, alliances and political oppositions and gives unequal access to instruments of power to particular actors.

The structure of this relational fabric results in political disputes polarized by groups associated with the political groups who hold institutional power. As the ordinary management of policies is dependent upon the mobilization of parts of the network, institutional office holders (especially elected ones) negotiate alliances with individuals from the policy community, exchanging positional power (originated from positions in the network) for institutional power (coming from positions in office). Still, this structure is also influenced by the political choices of relevant actors as these connections are built and broken throughout the policy process. In reality, changes in this fabric might be the result 
of deliberately political strategies by some governments, who face opposition to their policies from parts of the network (Marques, 2003).

Networks also configure the relations between the public and private domains, explaining State permeability. This is because individuals, organizations and companies from the inside or the outside of the State are connected by several types of intentional and non-intentional ties constructed throughout the life trajectories of individuals. In this sense, private companies operate by mobilizing their own positional power and by exchanging positional for economic power, breeding corruption. However, once again, political choices matter, and the strategies adopted by actors occupying the most important institutional offices affect the way in which permeability occurs.

\section{Urban Services}

A second variation of this pattern is present in urban services such as public transportation and garbage collection. These services used to be provided directly by public agencies until the 1980s, but nowadays they are also contracted out by local governments to private contractors in the vast majority of the cases. All important decisions concerning contracts are administrative and therefore taken by State agencies directly, with no legislative interference. Although similar to the previous pattern, some differences must be highlighted. A first important difference concerns the State agencies themselves. While in the previous governance pattern policies were produced by public companies, in this case they are formulated and implemented by agencies with lower insulation (departments and secretariats). These agencies usually do not have their own budget or their own revenue, and usually count on less stable bureaucracies, which migrate to and from other agencies, failing to develop a strong sense of community. All these elements reduce their insulation with respect to the private and political actors present in the policy community. A second group of differences concerns the private contractors. The State is again the sole or one of the sole buyers on this market, repeating the oligopsonic character of the market. But while in the previous case private contractors were hired to provide a service located in time and space (to build an infra-structure at a specific moment in time), in this governance pattern the contract involves the provision of a service for a certain period and in a certain spatially delimited region. While in the first case the State agencies must develop capacities to inspect and approve the products, in this case a much more sophisticated capacity must be developed - regulation.

In both cases the companies are interested in winning contracts and influencing the prices and quality of services. But while in the previous case quality was something quite technical, in this case it directly involves the services users - the citizens -, making this 
governance pattern politically more important. In this case, a key feature is the relationship between the financial arrangements of policies and the payment of private providers. These may be paid directly, but tariffs and taxes may also be deposited in a fund, together with public treasure funds, paying more to the providers than what is received from the system and generating subsidies to the services (such as buses in São Paulo). Additionally, while funding in the previous case involved 'investment', in this case it includes the 'operational costs' of managing the city. So, in periods of financial crisis, the previous governance pattern tends to shrink, but this one continues to work.

Community networks also bind contractors, bureaucrats and politicians together, but in this case the strength of the policy community is smaller and the role of external actors is therefore much larger. Large scale policy changes are also more common due to the lower insulation of the community. This may obviously be positive since the policies tend to be more accountable to electoral changes. On the other hand, these policy sectors may also have their key policy decisions influenced more easily by private interests. Due to these factors, corruption is also more common than in the previous governance pattern, although this obviously varies substantially.

\section{Large Urban Projects which Involve Exceptions to Urban Regula- tions}

The third subtype involves the decision and implementation of large urban projects and equipment, including urban renewal initiatives and the construction of large iconic buildings, which usually involve approving exceptions to land use and urban legislations. These processes are centered on local government actors, who coordinate closed decision processes within a network of actors connecting local politicians, construction companies, large scale developers and top municipal bureaucracies. In this case, the presence of foreign ideas about redevelopment, as well as of international actors involved in projects around the globe, is often substantial. In fact, this is the only governance pattern that receives a substantial influence of global flows of ideas, interests and projects.

This pattern mixes non-decisions (in the sense given to the term by Bachrach and Baratz, 1963) with specific decisions influenced through networks and State permeability. At least in São Paulo, major land use and zoning legislations such as Master Plans, Land Use and Zoning laws are approved in the legislative under pressure by several actors and social groups, in opened and conflictive processes characteristic of the production of regulatory policies (Lowi, 1964). This was the case of the 2002 Master Plan (the first approved by the local legislative since 1972) and the Land Use Law that followed it. In both cases the development industry and several 'not in my backyard' associations from rich neighborhoods 
managed to reduce the impact of distributive instruments included in the Plan by the leftwing government. Regardless of the results, the process was open and relatively participative, but these regulations approved from time to time remain as frozen references.

Differently, when large projects are created, it is quite common that substantial changes in urban regulations are approved for specific regions of the city. One way to do this is through the so-called Urban Operations, which allow the government to relax building and urbanistic parameters in delimited areas of the city to implement large scale renewal projects. To operationalize these Operations, the municipal government sells building potential (above the limits established by the law) to developers, in a strategy to capture land surpluses for the State. Although there must be formal approvals by the local legislative, which establishes the details of the Operations, including their perimeter, these happen in quite closed decision-making processes. These projects involve mainly top municipal decision makers, aldermen and developers in decision making, and bureaucracies in their implementation. Citizens and organized civil society actors stay away from these processes, which feed informal political grammars and corruption. Local politicians and aldermen participate in the process, both within the limits of the coalition presidentialism already discussed. On the other hand, the connections between construction firms, development companies and political parties are yet to be studied. The broad future of the city is usually decided on by these investments, which involve special zoning schemes for large areas of the city, changing land values, traffic and infrastructure and employment distribution (Bonduki, 2010).

This governance subtype is also marked by the fact that land is not really governed in Brazil, at least not in the active sense of planning. In fact, the large majority of Brazilian local governments try to avoid the political conflicts associated with the redistributive character of land policies, but at the same time benefit the interests of specific developers. Therefore, regardless of all the increase in participation in social policies in Brazil (which involve a specific governance pattern discussed in Marques, 2012), the decisions about the most important local development strategies remain concentrated within the government and influenced by the same economic forces that were important in the 1970s and 1980s. This happens mainly through non-institutionalized influence, maintaining the pattern of covert action through social networks associated with State permeability.

This has been the case of the decision process that led to the largest public works in the 1980s and 1990s in São Paulo. These works reached around US $\$ 4.2$ billion and enabled the expansion of the business center to the Southeast (from Avenida Brigadeiro Faria Lima to the Berrini/Marginal Pinheiros region) within the perimeter of the Urban Operation. Much information about these projects in São Paulo, associated with the institutional format of "Operações Urbanas", is discussed in detail by Bonduki (2010). 


\section{Enforcement of Building Regulations and Construction Approval}

The last governance subtype is the simplest and is associated with small changes and the enforcement of urban regulations concerning zoning, building norms and construction approval. Zoning and building regulations are established by municipal laws, approved by the local legislative and enforced by municipal bureaucracies and agencies. In the case of regulatory policies, coalition formation for approving legislation tends to be very unstable, since it must be based on common interests and not on logrolling (Lowi, 1964). Although regulatory policies do represent a generalization of the rule, as stated by Lowi (1964), the establishment of exceptions is certainly specific and potentially very profitable. Consequently, important negotiations occur during the approval of these legislations, but the implementation of existing regulations involves piecemeal changes in what is and is not allowed, benefiting specific developers and constructors. A great part of these processes are in the hands of street-level bureaucracies and simultaneously involve decisions and (many) non-decisions.

In this case, changes in regulations involve intense lobbying processes (and corruption) of bureaucrats by individual builders and developers to interpret the law in their favor, as well as of aldermen to change specific points in the regulations (in some cases concerning only a small part of a block), leading to ad hoc specific changes that benefit very particular interests. In other cases, the governance of building regulations also involves the non-application or plain disobedience of rules, enabled by the discretionarity of street level bureaucracies. This may or may not be connected to broader electoral financial arrangements, since local aldermen are connected with electoral bases.

Considering the amount of detail presented, I have summarized the main features of these patterns in the chart below. As we can see, the types of issues involved in the decision making process are quite different. In the first two patterns the types of intervention, their location (punctual in the first and network-like in the second) and the contracts with private providers are the main issues at stake. The third pattern involves decisions about the type of project, its location and spatial limits and its urbanistic parameters (involving accepted exceptions of existing regulations), while in the fourth pattern the application of existing regulation in piecemeal projects is the main subject. Regarding the decision-making process, the two former patterns involve closed and technocratic processes, although with higher insulation in the first case. In fact, the fourth case involves just the administrative implementation of rules, but which we know are marked by discretionarity.

In all patterns, State bureaucracies, private companies and politicians are present, but involving different actors, specifically and with different characteristics. Street level bureaucrats, for example, are important only in the fourth governance pattern, and 
developers (probably the most discussed urban private actor) are relatively unimportant in the first two patterns. In the first three patterns, actors are connected by community networks centered on the relational fabric of the State, with decreasing centrality of the state agencies responsible for the policy and increasing fragmentation. In the fourth case, actors are connected by fragmented connections. In all governance patterns, the local legislative tends to be irrelevant, except for the third case, when the approval of legislation is necessary, as in the fourth type, but with aldermen acting as individuals.

Finally, location and land tend not to be an issue in the first two patterns, especially involving legal expropriations to allow construction. In the third pattern, location and land are at the center of the whole governance pattern, since interests are localized, as is the distribution of projects gains. The situation is similar in the last case, but regarding only the location of the project/building under discussion.

Chart 1. Main features of the four governance patterns of built environment production

\begin{tabular}{|c|c|c|c|c|}
\hline $\begin{array}{l}\text { Governance } \\
\text { patterns }\end{array}$ & $\begin{array}{l}\text { Large infra-structure/ } \\
\text { public companies }\end{array}$ & Urban services & $\begin{array}{l}\text { Large urban proj- } \\
\text { ects which involve } \\
\text { exceptions to urban } \\
\text { regulations }\end{array}$ & $\begin{array}{l}\text { Enforcement of build- } \\
\text { ing regulations and } \\
\text { construction approval }\end{array}$ \\
\hline Main decisions & $\begin{array}{l}\text { Types and location of } \\
\text { public works; } \\
\text { construction contracts }\end{array}$ & $\begin{array}{l}\text { Types of services; } \\
\text { location; } \\
\text { service provision } \\
\text { contracts }\end{array}$ & $\begin{array}{l}\text { Location; } \\
\text { urbanistic parameters; } \\
\text { construction contracts }\end{array}$ & $\begin{array}{l}\text { Approval of develop- } \\
\text { ments, buildings and } \\
\text { reforms }\end{array}$ \\
\hline $\begin{array}{l}\text { Decision } \\
\text { process }\end{array}$ & $\begin{array}{l}\text { Very closed (tech- } \\
\text { nocratic with } \\
\text { permeability) }\end{array}$ & $\begin{array}{l}\text { Very closed (tech- } \\
\text { nocratic with } \\
\text { permeability) }\end{array}$ & $\begin{array}{l}\text { Relatively closed } \\
\text { (approved by local } \\
\text { chambers) }\end{array}$ & $\begin{array}{l}\text { Administrative } \\
\text { (implementation } \\
\text { discretionarity) }\end{array}$ \\
\hline $\begin{array}{l}\text { Degree of } \\
\text { Insulation }\end{array}$ & High (state agencies) & Low (departments) & Low (departments) & Low (departments) \\
\hline Relevant actors & $\begin{array}{l}\text { State agencies and } \\
\text { bureaucracies; } \\
\text { construction } \\
\text { companies; } \\
\text { top decision makers/ } \\
\text { politicians }\end{array}$ & $\begin{array}{l}\text { Bureaucracies; service } \\
\text { providers; } \\
\text { top decision makers/ } \\
\text { politicians }\end{array}$ & $\begin{array}{l}\text { Bureaucracies; } \\
\text { land owners; } \\
\text { development industry; } \\
\text { top decision makers/ } \\
\text { politicians }\end{array}$ & $\begin{array}{l}\text { Street level } \\
\text { bureaucracies; } \\
\text { land owners; } \\
\text { development industry; } \\
\text { ordinary citizens; } \\
\text { street level politicians/ } \\
\text { aldermen }\end{array}$ \\
\hline $\begin{array}{l}\text { Relations be- } \\
\text { tween actors }\end{array}$ & $\begin{array}{l}\text { Community network } \\
\text { tightly centered on the } \\
\text { relational fabric of the } \\
\text { State }\end{array}$ & $\begin{array}{l}\text { Community network } \\
\text { loosely centered on the } \\
\text { relational fabric of the } \\
\text { State }\end{array}$ & $\begin{array}{l}\text { Community network } \\
\text { loosely centered on the } \\
\text { relational fabric of the } \\
\text { State and segmented } \\
\text { by spatial and political } \\
\text { cleavages }\end{array}$ & $\begin{array}{l}\text { Fragmented connec- } \\
\text { tions between actors }\end{array}$ \\
\hline $\begin{array}{l}\text { Legislative/ } \\
\text { aldermen }\end{array}$ & Irrelevant & Irrelevant & $\begin{array}{l}\text { Approved at local } \\
\text { chambers - } \\
\text { aldermen relevant as } \\
\text { individuals within } \\
\text { policy networks }\end{array}$ & $\begin{array}{l}\text { Aldermen relevant as } \\
\text { individuals }\end{array}$ \\
\hline $\begin{array}{l}\text { Space and } \\
\text { urban land }\end{array}$ & $\begin{array}{l}\text { Not very important, } \\
\text { concerning only legal } \\
\text { expropriations }\end{array}$ & Not very important. & $\begin{array}{l}\text { Very important in } \\
\text { terms of location and } \\
\text { limits, but also con- } \\
\text { sidering effects on the } \\
\text { land market }\end{array}$ & $\begin{array}{l}\text { Important, but very lo- } \\
\text { calized in terms of both } \\
\text { interests and effects }\end{array}$ \\
\hline
\end{tabular}




\section{Conclusion}

As we have seen, the Latin American literature has incorporated the concept of governance with several different meanings. Predominantly, however, governance has been used to describe: i. State efficiency, reachable through State reforms; ii. Participatory processes in public policies, understood as local and deliberative democracy. Although these two uses of the concept are considered opposite by the authors involved in each debate, they have several similarities. They are both based on prescriptive perspectives and associate governance with good, efficient, democratic and horizontal government, regardless of the ways in which these elements may be defined.

I agree that governance can be a very useful concept for studying governments and State actions in the region, but only if the concept is redefined. The concept must incorporate both good and bad government actions, as well as institutions, actors and the networks that bind them together. Both formal and informal relationships must be considered, as well as illegal processes and practices. Additionally, several different kinds of governance patterns may coexist in different policy areas at the same time (or even on different levels of the same one). Only if the whole variability of the political processes and institutional designs which surround and structure policy production are taken into account will comparisons be possible, enhancing the accumulation of knowledge about the relationships between politics and policies.

From this critical discussion of the literature, I define governance as sets of State and non-State actors interconnected by formal and informal ties operating within the policy-making process and embedded in specific institutional settings. With this concept in mind, I discussed here the presence of at least four broad governance patterns in urban policies targeted at the production of the built environment in Brazil. These patterns organize the production of policies on: i. large infra-structure policies, ii. urban services, iii. large projects, and iv. daily enforcement of land use and construction regulations. These patterns coexist with each other, and involve different features such as different groups of actors, degrees of State insulation, accountability and participation and specific institutional designs. The importance of the space and location of the projects also varies substantially.

If we travel from the first to the fourth pattern, we will find greater importance of urban space, land and location, as well as of the local legislatives (and their actors). At the same time, the patterns will present less bureaucratic insulation. Their networks will be more fragmented and less centered around State agencies and the relational fabric of the State. While construction companies and service provides are the main private interests 
in the first two patterns, developers appear at the center of the last two, although builders will still be present, but with less importance.

This suggests a preliminary interpretation of the issue. Governance patterns of urban policies are apparently the product of different combinations of the spatial characteristics of the issues at stake in each governance pattern (which influence the 'list' of interests involved), as well as of the institutional and organizational structures created to formulate and implement the policies (which also 'add' other actors). Policy and urban legacies, as well as previous network structures, influence and specify the combinations of the two broad elements cited above.

However, only the production of studies about other cities and policies may confirm or change this analytical description and lead us to a better understanding of the main elements involved in the workings of the State, not only in Brazilian cities, but also abroad. The specificities of each case in terms of legacies, spaces, institutions and actors must be used as input for formulating broader interpretations. An agenda organized around those elements may help us bridge the gap between policies and politics in cities, going beyond governments, but still considering the centrality of States.

Revised by Priscila Moura

Submitted in June 2013

Accepted in November 2013

\section{References}

ABERS, Rebecca; KECK, Margareth (2009), Mobilizing the State: The Erratic Partner in Brazil's Participatory Water Policy. Politics \& Society, vol.37, p. 289-314.

ANSELL, Christopher (2012), Collaborative governance. In: Levi-Faur, David. Oxford Handbook of governance. Oxford: Oxford University Press.

ARAÚJO, Sérgio (2002), Conceituação de governabilidade e governança, da sua relação entre si e com o conjunto da reforma do Estado e do seu aparelho. Textos para discussão ENAP, $\mathrm{n}^{\circ} 45$.

ARRETCHE, Marta (2012), Democracia, federalismo e centralização no Brasil. Rio de Janeiro: Ed. FGV/Ed. Fiocruz/CEM.

AZEVEDO, Sérgio; MARES-GUIA, Virgínia (2000), Governança metropolitana e reforma do Estado: o caso de Belo Horizonte. Revista Brasileira de Estudos Urbanos e Regionais, $\mathrm{n}^{\circ}$ 3, pp.131-144.

AZEVEDO, Sérgio (2000), Políticas públicas e governança em Belo Horizonte. Cadernos Metrópole. $\mathrm{n}^{\mathrm{o}} 3$, pp.65-79.

BACHRACH, Peter; BARATZ, Morton (1963), Decisions and Nondecisions: An Analytical Framework. The American Political Science Review, vol. 57, no 3, pp. 632-642. 
BONDUKI, Nabil (2010), Gestão, organização e financiamento do solo urbano. Internet:http:// www. cedeplar.ufmg.br/pesquisas/pis/Estudo\%2028.pdf, 2012.

BOSCHI, Renato (2003), Democratic Governance and Participation: Tales of Two Cities In: McCarney, Patrícia L. \& Stren, Richard E. (eds) Governance on the Ground: Innovations and Discontinuities in Cities of the Developing World. Baltimore and London, Johns Hopkins University Press.

BRESSER PEREIRA, Luis Carlos (1997), A reforma do Estado nos anos 1990: lógica e mecanismos de controle. Cadernos MARE, nº1.

BRESSER PEREIRA, Luis Carlos (2001), "Do Estado patrimonial ao gerencial". In: PINHEIRO, Paulo; WOLHEIM, Jorge e SACHS, Ignacy, ed. Brasil: um século de transformações. São Paulo: Companhia das Letras.

CARDOSO, Adauto; VALLE, Cleber (2000), Habitação e governança urbana: avaliação da experiência em 10 cidades brasileiras. Cadernos Metrópole - $\mathrm{n}^{0} 4$.

CARDOSO, Fernando Henrique (1970), Planejamento e política: os anéis burocráticos. In: LAFER, Bety. Planejamento no Brasil. São Paulo Ed. Perspectiva.

CKAGNAZAROFF, Ivan (2009), Reflexões sobre estratégias de governança local. Revista Gestão e Sociedade, vol. $3, \mathrm{n}^{\circ} 5$.

CORTES, Soraya V. and GUGLIANO, Alfredo. (2010), Entre neocorporativistas e deliberativos: uma interpretação sobre os paradigmas de análises dos fóruns participativos no Brasil. Sociologias, vol. 12, $\mathrm{n}^{\mathrm{O}} 24$.

DINIZ, Eli (2003), Reforma do Estado e governança democrática: em direção à democracia sustentada? Paper presented at Seminário Democracia, gobernanza y bienestar en las sociedades globales. Barcelona.

FARAH, Marta (2007), Continuidade e disseminação de inovações na gestão pública subnacional no Brasil. Paper presented at the XXI International Congress on State Reform.

FIGUEIREDO, Argelina; LIMONGI, Fernando (1999), Executivo e Legislativo na nova ordem constitucional. Rio de Janeiro: FGV.

FIORINA, Moris (1989), Congress: Keystone of the Washington Establishment. New Haven: Yale University Press.

FREY, Klaus (2007), Governança Urbana e Participação Pública, RAC eletrônica, $\mathrm{n}^{\circ}$ 1, vol. 1, pp. 136-150.

GURZA LAVALLE, Adrián; CASTELLO, Graziella; BICHIR, Renata (2008), The backstage of civil society: Protagonism, networks, and affinities between civil organizations. In: São Paulo, Brighton: IDS.

HARDING, Alan. (1997), Urban regimes in a Europe of the cities?. European urban and regional studies, vol. 4, nº4, pp.291-314.

IVO, Anette (1997), Uma racionalidade constrangida: a experiência da governança urbana em Salvador, CADERNO CRH, Salvador, n 26/27, pp.107-145, Jan. /Dec. 
JACOBI, Pedro (2005), Governança institucional de problemas ambientais. Política e sociedade, vol. $4, \mathrm{n}^{0} 7$.

KOOIMAN, Jan; BAVINCK, Maarten; CHUENPAGDEE, Ratana; MAHON, Robin; PULLIN, Roger (2008), Interactive governance and governability: an introduction. The Journal of Transdisciplinary Environmental Studies, vol. 7, $\mathrm{n}^{\circ} 1$.

LAUMANN, Edward and KNOKE, David (1987), The organizational state: social choice in the national policy domains. Madison: University of Wisconsin Press.

LE GALÈS, Patrick (2011), Urban policies in Europe: what is governed?. Bridge, Garyand Watson, Sohie, ed. The New Blackwell Companion to the City. Oxford: Blackwell.

LESSA, Carlos and DAIN, Sulamis (1982), Capitalismo associado: algumas referências para o tema Estado e desenvolvimento. In: BELLUZO, Luiza and COUTINHO, Renata, ed. Desenvolvimento capitalista no Brasil: Ensaios sobre a crise. São Paulo: Ed Brasiliense.

LEVI-FAUR, David (2012). Oxford Handbook of Governance. Oxford: Oxford University Press.

LOWI, Theodore (1964) American Business, Public Policy, Case-Studies, and Political Theory. World Politics. vol. 16, nº4, pp. 677-715.

MARQUES, Eduardo (2000), Estado e redes sociais: Permeabilidade e coesão nas políticas urbanas no Rio de Janeiro. Rio de Janeiro: Revan/Fapesp.

MARQUES, Eduardo (2003), Redes sociais, Instituições e Atores Políticos no governo da cidade de São Paulo. São Paulo: Ed. Annablume/Fapesp.

MARQUES, Eduardo (2005), A dinâmica imobiliária de incorporação em período recente”. In: MARQUES, Eduardo and TORRES, Haroldo, ed. São Paulo: segregação, pobreza urbana e desigualdade social. São Paulo: Ed. Senac, pp.3-240.

MARQUES, Eduardo (2012), Governing São Paulo - governance patterns in a highly unequal metropolis. Paper presented at the Meeting of the Global Governance Club, Copenhagen.

MOLOTCH, Harvey (1976), The city as a growth machine: toward a political economy of place. The American Journal of Sociology. vol. 82, $\mathrm{n}^{0} 2$, pp.309-332.

MOORE, Mike (1993), Declining to learn from the East? The World Bank and 'governance and development. IDS Bulletin, vol.24, ${ }^{\circ} 1$.

OECD. (1995), Governance in Transition: Public management reforms in OECD countries. Paris, OECD.

PIERRE, John (2011), The politics of urban governance. Londres: Palgrave McMillan.

RHODES, Rod. (1996), The new governance: governing without government. Political Studies, 46 , p. $652-667$.

RHODES, Rod (2006), Policy network analysis. In: GOODIN, R., ed. Oxford handbook of public policy. pp.425-447.

RIBEIRO, Luis (2012), As metrópoles brasileiras no milênio - resultados de um projeto de pesquisa. Rio de Janeiro: IPPUR/Observatório das Metrópoles. 
SADER, Eder (1988), Quando novos personagens entram em cena. São Paulo: Paz e Terra.

SANTOS JR., Orlando (2002), Democracia, desigualdades e governança local: dilemas da reforma municipal no Brasil. Cadernos Metrópole, $\mathrm{n}^{\circ}$ 8, pp. 87-103.

SHIMBO, Lúcia (2012), Habitação social de mercado: a confluência entre Estado, empresas construtoras e capital financeiro. Belo Horizonte: C/Arte.

SPINK, Peter. (1999). Possibilidades Técnicas e Imperativos Políticos em 70 anos de Reforma Administrativa. In: BRESSER-PEREIRA, Luiz Carlos; SPINK, Peter. (org.). Reforma do Estado e Administração Pública Gerencial. Rio de Janeiro: FGV, 1999.

STOKER, Gerry (1998), Governance as theory: five propositions. International Social Science Journal. vol. 50, $\mathrm{n}^{\circ} 155$, pp. 17-28.

STONE, Clarence (1993), Urban regimes and the capacity to govern: a political economy approach. Journal of Urban Affairs. vol. 15, nº1, pp. 1-28.

TATAGIBA, Luciana (2011), Relação entre movimentos sociais e instituições políticas na cidade de São Paulo. O caso do movimento de moradia. In: KOWARICK, Lúcio and MARQUES, Eduardo. (ed.) Caminhos cruzados: sociedade, política, cultura. São Paulo, Ed. 34.

WILSON, Robert (2000), Understanding governance: an international perspective. Revista de Administração de Empresas. vol. 40, nº20, pp. 51-63.

WILSON, Robert; SPINK, Peter; WARD, Peter (2011), Governança metropolitana nas Américas. Cadernos Metrópole. São Paulo, vol. 13, nº. 25, pp. 1-33.

WORLD BANK (1989), Sub-Saharan Africa. From crisis to sustainable growth. Washington: World Bank.

WORLD BANK. (1992), Governance and Development. Washington: World Bank. 